\title{
Article
}

\section{Heroes as Heritage: the commoditization of sporting achievement}

\author{
Gammon, Sean
}

Available at http://clok.uclan.ac.uk/10980/

Gammon, Sean ORCID: 0000-0001-5053-8763 (2014) Heroes as Heritage: the commoditization of sporting achievement. Journal of Heritage Tourism, 9 (3). pp. 246-256. ISSN 1743-873X

It is advisable to refer to the publisher's version if you intend to cite from the work. http://dx.doi.org/10.1080/1743873X.2014.904321

For more information about UCLan's research in this area go to

http://www.uclan.ac.uk/researchgroups/ and search for < name of research Group>.

For information about Research generally at UCLan please go to http://www.uclan.ac.uk/research/

All outputs in CLoK are protected by Intellectual Property Rights law, including Copyright law. Copyright, IPR and Moral Rights for the works on this site are retained by the individual authors and/or other copyright owners. Terms and conditions for use of this material are defined in the policies page.

\section{CLoK}

Central Lancashire online Knowledge www.clok.uclan.ac.uk

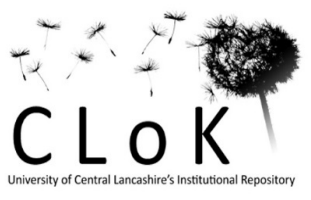




\section{Heroes as heritage: the commoditization of sporting achievement}

\section{Sean J. Gammon}

To cite this article: Sean J. Gammon (2014) Heroes as heritage: the commoditization of sporting achievement, Journal of Heritage Tourism, 9:3, 246-256, DOI: 10.1080/1743873X.2014.904321

To link to this article: http://dx.doi.org/10.1080/1743873X.2014.904321

\section{Published online: 10 Apr 2014.}

\section{Submit your article to this journal $\sqsubset$}

Џlll Article views: 626

Q View related articles $\square$

View Crossmark data ऍ

Citing articles: 2 View citing articles 5 


\title{
Heroes as heritage: the commoditization of sporting achievement
}

\author{
Sean J. Gammon* \\ School of Sport, Tourism and the Outdoors, The University of Central Lancashire, Preston, UK
}

(Received 3 December 2013; accepted 11 March 2014)

\begin{abstract}
The paper aims to explore and develop discussion relating to sports heritage by introducing the proposition that sporting heroes can be equated to forms of both tangible and intangible heritage. It begins by identifying the nature and function of sports heroes, while delineating a basic sports hero typology based upon a dialectic process that drives the emotional responses of the spectator and/or fan. Furthermore, the paper explores the commoditization process of the sporting hero that reframes them into heritage "objects". These "objects" are, in turn, responsible for the intangible heritage achievements produced during their careers. It is argued that sports heroes represent a hitherto unexplored source of tourist interest (specifically related to authenticity and motivation) which may add to our understanding of heritage studies in general.
\end{abstract}

Keywords: sporting heroes; living heritage; authenticity; commoditization

\section{Introduction}

Given that heritage is a fluid concept that is continually socially constructed it is little surprise that contemporary studies are increasingly focussing upon its interpretive and experiential qualities (Kim \& Jamal, 2007; Park, 2014; Smith, 2006). Consequently, the idea of what heritage may or may not be has loosened somewhat, resulting in potentially new directions of research. Sport has been identified as being one such direction (Gammon \& Ramshaw, 2007), though studies have predominantly focused upon recognising and protecting important sports sites, venues, and stadia (Beauchampe \& Inglis, 2006; Inglis, 2004) rather than reflecting upon the less obvious manifestations of sports heritage. As a result there has been a notable lack of research and discussion that explores the more intangible features of sporting heritage as well as studies that further the debates of what might be generally considered as heritage.

Sports heroes are a fundamental element of the sporting landscape, and while being a popular topic in the sport history literature, has had scant coverage in works connected to heritage and tourism. Therefore, the primary aim of the paper is to discuss the actual and prospective linkages between sporting heroes and heritage. Moreover, the case will be made for living sporting heroes to be considered as a form of living heritage, and as a result to be recognised as attractions worthy of tourist experience and travel. Whilst the term "hero" generally refers to the great achievements and accomplishments of men, this

\footnotetext{
*Email:sjgammon@uclan.ac.uk
} 
is not the case in sport, and so when used in this paper we will refer to both sportsmen and sportswomen alike.

\section{Sporting heroes}

Debates surrounding the nature and purpose of heroes have attracted writers and commentators for millennia (Hughes-Hallett, 2004). The qualities of heroes are inherently difficult to pin down. From times of antiquity heroes have displayed often contradictory characteristics that, on the one hand, include feats of extraordinary greatness, sacrifice, and courage, while on the other, involve acts of selfishness, cruelty, and capriciousness. Some are revered as god-like - others as fragile, imperfect strugglers with feet of clay. Yet they are all noted as being exceptionally gifted in some ways, unique and powerfully inspirational whose maverick behaviour not only sets them apart from the rest but also ensures they stand alone. They can be law breakers as well as law makers, warriors, generals, politicians, philosophers, and many more. Modern sporting heroes are unsurprisingly a more recent feature upon the hero landscape; nevertheless, their inclusion and subsequent veneration spans more than two centuries (Barney, 1985; Crepeau, 1981; Holt, 1998; Hughson, 2009). It appears that sport needs heroes; that the many physical and mental challenges that sport often encompasses breeds individuals who are prepared to go beyond what is expected of them. Their deeds are rarely left unacknowledged by an adoring public who will defend and often elaborate a player's or athlete's achievements in a variety of fora. Accounts of their accomplishments can be found in the archives of clubs, libraries, museums, and halls of fame across the globe, yet the criteria that qualify them are opaque at best, and their purpose remains uncertain:

... a sport hero is like Hamlet without a Prince, and yet the varieties and purposes of sporting heroism are rarely examined. The sporting public is too busy worshipping to reflect on the objects of its fascination and those few whose business it is to take an analytical view have been absorbed in other things. (Holt \& Mangan, 1996, p. 5)

It has been suggested that the choice and depiction of heroes is culturally framed, as heroism is always measured and (re) evaluated against the societal values of the day. This assertion has led many to observe that sporting hero-worship in North America differs to that practiced in Europe; the former based upon winning and winning well, the latter on aesthetics and Corinthian spirit (Holt \& Mangan, 1996; Hughson, 2009; Rauch, 1996). Yet such distinctions fail to recognise the often transient nature of the hero; their adoration is not only dependent upon where they practise their trade - but also when. The stereotypical British portrayal of heroism, built upon understated great feats, tempered with humility and modesty have evolved into an appreciation for steadfastness, determination and triumph; characteristics more associated with American sporting culture. But heroes are hewn from many materials, some of which are undoubtedly more durable than others and some which display features that appeal to much wider audiences. The increasingly international nature of sport introduces and promotes new heroes; individuals whose triumphs are appreciated and assessed on a global scale.

There are more similarities than differences in how sporting heroes are chosen and defined, and when analysed collectively illustrate the various culturally driven nuisances and biases that contribute to our understanding of the term. For example, Barney (1985) sets out five very specific criteria: first, the hero must exhibit salient performance excellence - but such extraordinary abilities must be supported with the second criterion of moral excellence. They must behave with integrity and honesty both on and off the field of 
play. Heroes, according to Barney (1985), should also display strong altruistic tendencies, helping those less fortunate than themselves and/or inspiring others through support and unselfish deeds. The fourth criterion relates to the hero's ability to demonstrate theoretical and practical wisdom (Wann, Merrill, Russell, \& Pease, 2001). Heroes should live in accordance to the values of the culture which they inhabit - practising financial propriety as well as general clean-living. The final criterion is that hero status cannot be bestowed on sportspeople during their lifetime. It is hoped that the passing of time will ensure that any potential damaging evidence relating to a given athlete be revealed before their "enshrinement". Barney's (1985) heroes are virtuous and almost saintly, whose initial notable sporting deeds are worth little if they are not supported by a wholesome and untarnished life outside the sport. Time, it is argued, will tease out any unfortunate tales concerning these "heroes in waiting", and so will add a sense of perspective and objectivity before hero status is accorded. However, time has a tendency to mythologise and venerate the greats to such an extent that perspective is lost; this is often the case in sport (Gammon, 2002; Gammon \& Ramshaw, 2013; Redmond 1973). It is a truism that the further the passing of time, the more extraordinary the feats of heroism.

Hughson (2009) suggests, similar to Barney (1985), that their heroism can be considered as emanating from one or both of their prowess and morality. Hughson (2009) does not propose that a hero is either one or the other, though in some cases there are players who failed to deliver the same level of achievement in their private lives as they did in their sporting careers. There is clearly a tension between their sporting endeavours and the personal conduct expected of those who have been given such exceptional skills. These moral judgements (both on and off the field of play) are undoubtedly culturally situated and assessed, equating some behaviours (such as stretching the rules) being perceived by some as an artful display of overcoming authority, whilst others condemning them for blatant un-sportsman-like conduct. So, given such cultural diversity, is it possible to identify any salient characteristics which raise a sportsperson to heroic status? It appears that the literature tends to side-step the question, preferring to focus upon the function of heroes (discussed later in this paper) rather than nailing down specific features. As Bale (2006, p. 236) observes:

The contestation of heroic qualities confirms the fractured nature of "heroism", a quality that is geographically and socially partial. Rarely is it asked how heroic one has to be in order to achieve the status of hero.

Nevertheless, it is worth exploring some common traits and features most often alluded to when describing heroes in order to distinguish them from the simply gifted and talented of which there are numerous. Heroes are not just good at what they do, it is not, as Hughson (2009) points out, a simple process of identifying a career batting average or the number of wins a player or athlete accrued while competing, for it is as much to do with how such averages and successes were achieved, in what era, and under what conditions. For the deeds attained by the sporting hero, context is everything. In recent years there has been a steady dilution of the term hero, fuelled by a media that deals in hyperbole (Whannel, 1992) as well as a growing and ageing fan-base that nostalgically looks back upon a "golden age" of sport (Gammon \& Ramshaw, 2013). Barney's (1985) contention that heroes can only be labelled as such after they have died sits uncomfortably with a public who are happy to pay premium prices to see and experience the sporting heroes of the day. There is room, it appears, for the coexistence of the mythologised heroes of the past and the emerging heroes of the present. Indeed, the most vehement debates in sport 
often involve the aesthetic and technical comparisons of previous heroes with those still competing or recently retired. Previous studies suggest that sporting heroes should of course demonstrate extraordinary technical prowess - but demonstrating great skill is not enough; for the hero should exude character, especially in the face of adversity (Holt \& Mangan, 1996). Lines (2001) goes further, highlighting the very masculine qualities that we expect from heroes such as strength, bravery, competitiveness, and success, “... all traditionally perceived to develop through sporting endeavours" (Lines, 2001, p. 289). But the elevation to hero status is not always based upon winning - as in some cases it is about losing with grace or failing courageously (Pivato, 1996; Rauch, 1996). Above all, however, the hero must have achieved something - usually something that was beyond what would normally be accepted as possible; a feat that in simple terms separates them from the rest. Their actions are rarely wasted on events where the outcome is unimportant or incidental, for, "it is in times of emergency that heroes are looked for and found" (Hughes-Hallett, 2004, p. 4). The above criteria outline some of the prominent qualities required to attain hero status, though they are largely dependent upon interpretation and illustration, equating to many discussions found in the literature supported by case studies and portraits (Bale, 2006; Crepeau, 1981; Holt \& Mangan, 1996; HuntingtonWhiteley, 1998; Hughson, 2009). There is little doubt that while specific cases help to put many of the discussions on heroism in context they also illustrate the very subjective nature of hero choice and depiction.

To what extent sporting heroes, or indeed any form of hero, serve a purpose that transcends their specific achievements is clearly a moot point. Hughes-Hallett (2004) contends that a country that has no need of heroes is indeed a fortunate one; that it is out of desperation that people feel a need to crave and worship a great champion or saviour. Others have taken a less cynical view, maintaining that heroes provide us with an ultimate ideal that can be both inspirational and life-affirming: "The hero shows us what we ought to be, and we make him a hero because we wish to be what he is. He calls us beyond ourselves, towards the ideal" (Crepeau, 1981, p. 24). So heroes are not sought so much out of desperation but out of necessity, and therefore can be perceived as an integral element of any culture (Hofstede, Hofstede, \& Minkov, 2010). In many cases, as detailed earlier, the sports hero can be saddled with the nom de plume of role model for both adults and children alike (Biskup \& Pfister, 1999; Lockwood \& Kunda, 1997; Wann et al., 2001). This additional responsibility often pressurises both young and experienced sports people to promote morally acceptable lifestyles that can be at odds to the lives they genuinely lead. The extent and nature of such disparity, when exposed, can affect their hero status permanently (the revelations concerning Tiger Woods' private life may be a point in case). Additionally sporting heroes can act as potent instigators and symbols of nostalgia, offering what Wann et al. (2001) refer to as a compensatory function. Present day heroes and their deeds can reignite the great feats of yesteryear by encouraging the adoring fan of greatness past. Whereas retired heroes (if indeed heroes ever retire) act as living representations of a "superior" past that provides comfort and solace to those who hanker back to the days of their youth (Gammon \& Ramshaw, 2013). Such nostalgic sentiment generates a further more pragmatic economic function (fuelled by an ever increasing older demographic) which uses heroes as emotive commodities. For example, the appearance of a sports hero can increase gate receipts, and inductions into halls of fame can positively impact upon both the organisation and the region in which it is based.

Heroes then are culturally formed and situated. The interpretation of courage, skill, achievement and any other related criteria is socially determined, as is the extent that such achievements are valued and nurtured. They represent a cultural ideal that people 
wish to protect, celebrate and ultimately emulate. Much like heritage, heroes, along with their valued deeds and achievements, are cherished and recorded for future generations to acknowledge and revere. The degree in which sporting heroes can be considered bona fide heritage is unclear and represents the main discussion in the next section.

\section{The hero-heritage nexus}

The idea that heritage can be alive is not new, but the suggestion that a living individual can be a tangible heritage object has had scant coverage in the literature. Living heritage is more commonly associated with the intangible elements linked to an existing community's rituals, craftwork, music, or language (Deacon, 2004). It has also been described as the live interpretation found in living history museums such as Beamish in the UK - or in the numerous re-enactment displays that aim in recreating important battles and conflicts from the past (Smith, 2006). From a sporting context Ramshaw's (2010) study introduces an additional perspective to how the living can be critical features of a museum's products. His case study on the Olympic Hall of Fame and Museum at Canada Olympic Park in Calgary explored how watching Olympic athletes train had not only become an integral part of the museum visit but also fulfilled a number of legacy initiatives. White (2013) offers a more specific interpretation of living sporting heritage, arguing that Cathy Freeman became not only a potent symbol of Australia's heritage (through her achievements at the 2000 Olympic Games), but moreover that she personified and embodied the heritage of her country:

If we understand heritage as a process that constructs meaning about the past, then the construction of Cathy Freeman at the Sydney Games is illustrative of this process. It was, essentially, a visual construction of heritage based upon her body, her movements and the setting. (White, 2013, p. 166)

Freeman's sporting achievements (National, World and Olympic 400 metres Champion) certainly qualify her as a sporting hero, with her status galvanised through her success at the Sydney 2000 Games. Through her own ethnicity she became a powerful symbol for the struggles and injustices of indigenous Australians as well as a national hero of the predominant white population. She was the Australian poster girl for the 2000 Games which placed additional pressure and intense national expectation on her shoulders leading up to the 400 metres final. As discussed above, success is not in itself enough to elevate exceptional athletes to hero status - context is everything. Since Freeman's retirement in 2003 she has become involved in a number of charity initiatives and remains, for many, a national treasure (Stewart, 2013).

The term "national treasure" is often attributed to sporting heroes who have achieved a status that permeates beyond initial fan bases. However, to what extent that living sporting heroes can be perceived and/or interpreted as living tangible heritage is unclear. Categorisations of sporting heritage have been suggested, including the category of tangible moveable objects which broadly refers to the displays and artefacts transported for special sports exhibitions or museum relocation (Ramshaw \& Gammon, 2007). Intuitively, it would seem logical to consider living sporting heroes as a prime example of tangible moveable objects, yet the term "objects" implies an inanimateness that is at odds with the very living human qualities of the players and athletes in question. A very different relationship exists between the quiescent features of valued sporting artefacts and the corporeal qualities of the living. For example, those who have an interest in heritage are often influenced and impressed by 
the patina of age in some traditional tangible objects such as buildings and pieces of art. Sports heroes age and change - we cannot stop that - though their inextricable physical decline can at times sadden us, while simultaneously reminding us of our own mortality. We cannot preserve or protect them in the same way we can of other inanimate objects, but we can preserve and celebrate their deeds and achievements. Halls of fame and sports museums undoubtedly attempt to identify and celebrate achievements deemed important enough to record and pass on to future generations (Snyder, 1991). Also, statues are being increasingly used to celebrate and acknowledge sporting greats, and are viewed as tangible symbols which help vitalise and cement fan identities (Stride, Wilson, $\&$ Thomas, 2013). The living hero is then a conduit to the past; one who embodies the extraordinary achievements and experiences that so many admire and look up to. They are producers of intangible and tangible heritage through both the recording and marking of their accomplishments as well as through the collection of related personal sporting paraphernalia. If indeed heroes are perceived as a form of living heritage, then their heritage moment is but a fleeting one. There is little their adoring public can do to preserve them or to sympathetically restore them for the delectation of those who were not fortunate enough to witness their achievements first hand. We have to forgive their decline, as unlike conventional heritage objects the veneer of age inherent in the retired hero does not ennoble their status but can often detract and distract from their extraordinary achievements. And yet, they are still to be admired and gazed upon as authentic representations of the original that undeniably project, to many, the aura of the unique and irreplaceable (Benjamin, 1999). It is little wonder that the opportunity to see and listen to the greats has become big business (Fairley \& Gammon, 2005; Gammon \& Ramshaw, 2013). Evidently then, it would be misleading to suggest that the response to an ageing hero is always one of disappointment or regret. Many past heroes still compete, albeit at a lower level than in their prime; others have forged out new careers, accomplishing new goals - and by so doing have re-positioned themselves within the sporting lexicon.

Heritage commonly generates an emotional response from those that come in contact with it (Bagnall, 2003; Chen \& Chen, 2010). Sporting heroes are no different. The nature of the interaction (direct or vicarious) between hero and spectator is a complex one, and is largely dependent upon the extent of respect and worship involved. Nevertheless, the emotional response to the retired hero will be based upon an assessment between a hero's past and a hero's present. Therefore, a dialectic practice takes place whereby a spectator assesses and revisits the image(s) and achievements of a hero's past, with image(s) and events that have taken place since. As a consequence, hero assessment must be viewed as a process that potentially identifies a range of hero types; each of which share quite distinct relationships with sporting heritage. For example, some heroes go on to forge successful careers after they have retired from competition. This type of enriched heritage occurs when athletes' achievements, post retirement, add or eclipse those they accomplished as an athlete. Sebastian Coe's political career and subsequent leadership of the London 2012 Olympic Games or Franz Beckenbauer's football management and German ambassadorial triumphs may act as appropriate examples. But for many heroes, the often unremarkable and/or less visible careers chosen after their sporting successes mean that their heritage status is a faded one; where their past achievements remain the chief components of their heritage. But for some heroes the tension between the past and the present is more polemical, leading to what could be described as damaged heritage. This is likely to take place where there have been indiscretions since the hero's retirement, or when new misdemeanours from their playing careers are retrospectively examined. The ex-England soccer player Paul Gascoigne whose extraordinary achievements on the field have been marred 
by his subsequent fight with alcoholism and wife-beating charges may act as an appropriate example, as would the major league baseball batter Pete Rose's gambling charges leading to his permanent ineligibility to the baseball hall of fame. Others have fared worse, where their injudiciousness has been so extreme as to potentially wipe out any of their career achievements - however heroic they may have been. In this case the heritage is more broken than damaged and can be best illustrated in the recent doping revelations associated with Lance Armstrong. Whether Armstrong will ever be able to be recognised as anything other than a cheat remains to be seen, though his story may well remain as part of the darker, less palatable features of sports heritage. Of course any assessment of the past with the present will, as intimated earlier, generate a number of varying interpretations and conclusions. Much like other forms of heritage (Dann \& Seaton, 2001; Timothy \& Boyd, 2006; Tunbridge \& Ashworth, 1996), the interpretation of sporting heroism and moral character will vary depending upon specific cultural values and the extent of fan identification. For example, Diego Maradona's extraordinary and unquestionable abilities on the field have, for some, been tainted by his much publicised fight with drug and alcohol addiction. Moreover, the much debated "hand of god" incident during the 1986 World Cup generated a notable reevaluation of Maradona's hero status. It must be noted that the incident took place with the back-drop of the Falklands war, culminating in Maradona's hero status being firmly secured in Argentina as the young rascal genius while being labelled in England as an exceptionally gifted cheat (Archetti, 1997). A less obvious example of contested sporting heritage can be explored through the record-making achievements of Roger Bannister (Bale, 2006). Bannister is credited with being the first runner to break the four minute barrier for running a mile - and in doing so achieved athletic immortality (Huntington-Whiteley, 1998). And yet his achievement at the time (1954) was considered, by some, to be overly scientific and inappropriately contrived; arguing that the record should have taken place in normal competitive conditions, rather than the meticulously planned pace-setting circumstances that occurred on the day. Such sentiments exemplify the predominant Corinthian spirit inherent in British Athletics at the time.

Of course, like all heritage, the extent that a hero is valued and cherished is very much dependent upon a number of cultural and personal indicators; least of which is the degree of fandom attached to the hero (Gammon, 2012; Wann et al., 2001). Therefore, in some cases a hero's incautions may well be forgiven by an adoring public who prefer to focus upon an individual's sporting career, rather than their more human frailties. Indeed, such practices may well stem from a need to shield fans' self-esteem and beliefs as opposed to any selfless strategy to protect the reputation of the hero in question. Occasionally, when associated with the anti-hero it is, paradoxically, the questionable moral qualities that are equally celebrated and vilified over and above a sports person's prowess. John McEnroe's infamous tirades on court and seeming disregard for authority may act as an appropriate example (Hughson, 2009). Nevertheless, irrespective of how heroes are perceived and labelled, there is a good deal of evidence that their often global notoriety has made them into heritage tourist attractions in their own right.

\section{Tourism and the sporting hero - the commoditisation of sporting achievement}

Cohen's (1988, p. 380) assertion that commodification takes place when, “... things (and activities) come to be evaluated primarily in terms of their exchange value, in a context of trade, thereby becoming goods (and services)...", highlights the clinical and obvious economic nature of supply and demand in both sport and tourism domains. However, what the above definition accounts less for is the human objectification as commodity, 
along with the process whereby an object changes its commercial identity. The idea that human beings can be treated as commodities is not new (Appadurai, 1986) and, can, for example, be illustrated in the immoral practice of slavery (Kopytoff, 1986). But the idea that individuals can be perceived as heritage objects in their own right, and as a result generate tourism activity, has largely been neglected in the literature.

Linkages between sport and tourism are well founded (Gammon \& Kurtzman, 2002; Hinch \& Higham, 2011; Standeven \& De Knop, 1998; Weed \& Bull, 2009) and include studies that acknowledge the potential for the sporting past to ignite significant tourism receipts (Fairley \& Gammon, 2005; Gammon \& Ramshaw, 2007; Gibson, 1998; Ramshaw, Gammon, \& Huang, 2013). More specifically there have been increased discussions that explore the heritage of sport and its impact upon the study of heritage in general (Phillips, 2012; Ramshaw \& Gammon 2007). The most obvious instances where sporting heroes are directly used to attract visitors are through Masters' events and/or senior tours such as those popular in golf, tennis, and ice hockey (Ramshaw \& Hinch, 2006). The draw to such events has been chiefly framed and explained around the nostalgia literature or the heritage components of the events themselves. While, the experience of seeing heroes once more may produce nostalgic emotions, there will undoubtedly be other experiences and motives at work; particularly in seeing, first-hand, genuine heroes in action. The events will still have a strong competitive element to them, though understandably the level of competition will fall below either the level they played at in their prime or the level performed by current players. The motive appears not to see how they were but to get closer to how they are now, "they do not hit the ball as hard and are clearly not as athletic as they used to be, but this seems not to distract from the 'authenticity' of the event" (Fairley \& Gammon, 2005, p. 188).

To get even closer to sporting heroes, fantasy camps offer visitors the opportunity to directly interact with past heroes by creating camps whereby attendees will play and train alongside the sport stars of the past (Gammon, 2002). Camps will often incorporate sporting venues that are connected in some way to the team or player that determine its primary selling point, equating to the ultimate sporting experience:

For the campers, regular guys for all walks of life, it's heaven. They share locker rooms with the retired stars, and meals and social time, gleaning in their knowledge and becoming raptured with their lore. (Schlossberg, 1996, p. 112)

The least studied demonstration of the commoditization of sport heroes are the increasingly popular special appearance events whereby sporting greats will (for, at times, a considerable fee) discuss their careers with a live audience. In some case, events will involve photo sessions with the sport hero as well fine dining and other related speakers. Wayne Gretzky (a Canadian ice hockey icon) uses these types of appearances to raise funds for his own charity-based foundation and in doing so reinforces his already extraordinary hero status. Depending on the notoriety of the hero, tickets can demand high prices and will be affected by the chance or promise of some forms of interaction with the hero. For example, "an evening with" Wayne Gretzky can cost around \$1999.00 (CDN) (Frameworth Sports Marketing, 2013). Additionally, heroes can be used to enrich and support other products and services. Stadium tours are now an accepted offering for the majority of major sporting venues and will range in their complexity and popularity (Ramshaw et al., 2013). For a premium price many tours (e.g. Emirates stadium: Arsenal FC) will include an ex star of the club to show patrons around - sharing anecdotes and signing photographs, etc.

As intimated above authenticity is an important element of the visitors experience at such events. To take a dualistic perspective, there is an authenticity to the bodies the heroes inhabit 
and so they offer insights that are unlikely to be divorced from reality. The demand for visitors, to see them in the flesh, indicates their importance to not just the sporting landscape but to the broader cultural fabric too. This may indicate that the sports hero has become no different from other notable celebrities; that it is their simple notoriety that perpetuates the public's curiosity towards them. For example, Turner (2014) believes that "the desire for the authentic - to reach the core of the personality, to find out what 'they are really like' - is as fundamental to the sports fans as to the film fan" (p. 24). It is beyond the scope of this paper to explore the definitional vagaries and complexities of the term celebrity, as this has been discussed in some detail elsewhere (Monaco, 1976; Rojek, 2001, 2012; Turner, 2014). Nevertheless, it is worth pointing out that there appears no clear consensus as to whether sports heroes are in some way separate from celebrity (Boorstin, 1971; Shuart, 2007) or, as Rojek (2001) and Drucker (1997) argue, are in fact one in the same thing. There is undoubtedly a case to be made that sporting heroes have become part of the celebrity culture inherent in many developed societies, yet this demeans their standing and durability. There is a shadow of ephemerality and superficiality that runs through the term celebrity, indicated by its likely Latin route of celere - meaning swift. It may be the case that their time in the spot-light is fleeting but their deeds and accomplishments can live on for generations. There is a good deal of evidence that fans and followers will pursue their heroes and pay a premium price to get close to them, yet their motives and experiences require further investigation by both sport and tourism scholars alike.

\section{Conclusion}

The extent in which sporting heroes can be interpreted as tangible manifestations of living heritage is unclear but the case that their achievements be considered as intangible heritage is less contentious. Our rejection of living heroes being considered as heritage objects undoubtedly stems from their obvious finite qualities. From an anatomical viewpoint they are not much different from those who worship them; for it is what their bodies have achieved and experienced that separates them from the ordinary. In this sense they are no different than the more conventional structures we bestow the status of heritage to. If indeed we are to accept that heritage is in the eye of the beholder and that nothing truly has inherent heritage qualities then the case for living heroes may be more confidently made. Sporting heroes personify the limitless boundaries of sporting achievement and so remind those less able of what can be realised in their own lives. Yet, in some cases the hero struggles to carve out new life directions - and to set out new goals. They carry around with them the often heavy weight of their own sporting achievements, which in turn prevents them from making a successful life away from the gaze of the fan. Others will use their sporting achievements as a vehicle to new career paths and successes, and in doing so, reposition their hero status. But whatever their heritage status, whether enriched, faded, damaged, contested - or even broken, there will always be an audience prepared to experience them in the flesh one last time. There is little doubt that demand to see and get close to them makes heroes a much desired commodity, and establishes many of them as an integral part of sports heritage and beyond.

\section{References}

Appadurai, A. (Ed.). (1986). The social life of things. Commodities in cultural perspective. Cambridge: Cambridge University Press.

Archetti, E. P. (1997). And give joy to my heart. Ideology and emotions in the Argentinian cult of Maradona. In G. Armstrong \& R. Guilianotti (Eds.), Entering the field. New perspectives on world football (pp. 3-52). Oxford: Berg. 
Bagnall, G. (2003). Performance and performativity at heritage sites. Museum and Society, 1(2), $87-103$.

Bale, J. (2006). How much of a Hero? The fractured image of Roger Bannister. Sport in History, $26(2), 235-247$.

Barney, R. K. (1985). The hailed, the haloed, and the hallowed: Sport heroes and their qualities - An analysis and hypothetical model for their commemoration. In Müller, N. Rühl, J. K. (Eds.), Olympic scientific congress sport history. July 19-26, 1984 (pp. 88-103). Niedernhausen: University of Oregon, Eugene/Oregon, Official Report.

Beauchampe, S., \& Inglis, S. (2006). Played in Birmingham. Charting the heritage of a city at play. Birmingham: English Heritage.

Benjamin, W. (1999). Illuminations (H. Arendt, Trans.). London: Pimlico.

Biskup, C., \& Pfister, G. (1999). I would like to like her/him: Are athletes role-models for boys and girls? European Physical Education Review, 5(3), 199-218.

Boorstin, D. (1971). The image: A guide to pseudo-events in America. New York: Atheneum.

Chen, C. F., \& Chen, F. S. (2010). Experience quality, perceived value, satisfaction and behavioural intentions for heritage tourists. Tourism Management, 31, 29-35.

Cohen, E. (1988). Authenticity and commoditization in tourism. Annals of Tourism Research, 15(3), $371-386$.

Crepeau, R. (1981). Sport heroes and myth. Journal of Sport and Social Issues, 5(23), 23-31.

Dann, G. M. S., \& Seaton, A. V. (2001). Slavery, contested heritage and thanatourism. International Journal of Hospitality \& Tourism Administration, 2(3/4), 1-29.

Deacon, H. (2004). Intangible heritage in conservation management planning: The case of Robben Island. International Journal of Heritage Studies, 10(3), 309-319.

Drucker, S. (1997). The mediated sports hero. In S. Drucker \& R. Cathart (Eds.), The mediated sports hero. American heroes in middle age (pp. 82-96). Creskill, NJ: Hampton.

Fairley, S. and Gammon, S. (2005). Something lived, something learned: Nostalgia's expanding role in sport tourism. Sport in society: Cultures, commerce, Media, Politics, 8(2), 182-197.

Frameworth Sports Marketing. (2013). A very special evening with Wayne Gretzky. Retrieved from http://frameworth.com/cart/skin1/images/Gretzky.pdf

Gammon, S. (2002). Fantasy, nostalgia and the pursuit of what never was. In S. Gammon \& J. Kurtzman (Eds.), Sport tourism: Principles and practice (pp. 61-71). Eastbourne: LSA Publications.

Gammon, S. (2012). Sports events: Typologies, people and place. In S. J. Page \& J. Connell (Eds.), The Routledge handbook of events (pp. 104-118). London: Routledge.

Gammon, S., \& Kurtzman, J. (Eds). (2002). Sport tourism: Principles and practice. Eastbourne: LSA Publications.

Gammon, S., \& Ramshaw, G. (2007). Heritage, sport and tourism: Sporting pasts - Tourist futures. London: Routlege.

Gammon, S., \& Ramshaw, G. (2013). Nostalgia and sport. In A. Fyall \& B. Garrod (Eds.), Contemporary cases in sport (pp. 201-219). London: Goodfellow.

Gibson, H. (1998). Sport tourism: A critical analysis of research. Sport Management Review, 1(1), $45-76$.

Hinch, T., \& Higham, J. (2011). Sport tourism development. Clevedon: Channel View.

Hofstede, G. H., Hofstede, G. J., \& Minkov, M. (2010). Cultures and organizations: Software of the mind: International cooperation and its importance for survival. London: McGraw-Hill.

Holt, R. (1998). Champions, heroes and celebrities: Sporting greatness and the British public. In J. Huntington-Whiteley (Ed.), The Book of British sporting heroes (pp. 12-25). London: National Portrait Gallery.

Holt, R., \& Mangan, J. A. (1996). Prologue: Heroes of a European past. In R. Holt \& J. A. Mangan (Eds.), European heroes. Myth, identity, sport. London: Frank Cass.

Hughes-Hallett, L. (2004). Heroes. A history of hero worship. New York: Anchor Books.

Hughson, J. (2009). On sporting heroes. Sport in Society: Cultures, Commerce, Media, Politics, 12(1), $85-101$.

Huntington-Whiteley, J. (1998). The Book of British sporting heroes. London: National Portrait Gallery.

Inglis, S. (2004). Played in Manchester. The architectural heritage of city at play. London: English Heritage.

Kim, H. and Jamal, T. (2007). Tourist quest for existential authenticity. Annals of Tourism Research, 34(1), 181-201. 
Kopytoff, I. (1986). The cultural biography of things: Commoditization as process. In A. Appadurai (Ed.), The social life of things. Commodities in cultural perspective (pp. 64-94). Cambridge: Cambridge University Press.

Lines, G. (2001). Villains, fools or heroes? Sports stars as role models for young people. Leisure Studies, 24(4), 285-303.

Lockwood, P., \& Kunda, Z. (1997). Superstars and ME: Predicting the impact of role models on the self. Journal of Personality and Social Psychology, 73(1), 91-103.

Monaco, J. (Ed.). (1976). Celebrity. The media as image makers. New York: Delta.

Park, H. Y. (2014). Heritage tourism. London: Routledge.

Phillips, M. G. (Ed.). (2012). Representing the sporting past in museums and halls of fame. London: Routledge.

Pivato, S. (1996). Italian cycling and the creation of a catholic hero: The Bartali myth. In R. Holt, J. A. Mangan, \& P. Lanfranchi (Eds.), European heroes. Myth, identity, sport (pp. 128-138). London: Frank Cass.

Ramshaw, G. (2010). Living heritage and the sports museum: Athletes, legacy and the Olympic hall of fame and museum, Canada Olympic park. Journal of Sport and Tourism, 15(1), 45-70.

Ramshaw, G., \& Gammon, S. (2007). More than just nostalgia? Exploring the heritage sport tourism nexus. In S. Gammon \& G. Ramshaw (Eds.), Heritage, sport and tourism: Sporting pasts tourist futures (pp. 9-21). London: Routledge.

Ramshaw, G., Gammon, S., \& Huang, W. (2013). Acquired pasts and the commodification of borrowed heritage: The case of the bank of America stadium tour. Journal of Sport and Tourism, $18(1), 17-31$.

Ramshaw, G., \& Hinch, T. (2006). Place identity and sport tourism: The case of the heritage ice hockey event. Current Issues in Tourism, 5(4-5), 399-418.

Rauch, A. (1996). Courage against cupidity: Carpentier and dempsey - symbols of cultural confrontation. In R. Holt, J. A. Mangan, \& P. Lanfranchi (Eds.), European heroes. Myth, identity, sport (pp. 156-168). London: Frank Cass.

Redmond, G. (1973). A plethora of shrines: Sport in the museum and the hall of fame. Quest, 19, $41-48$.

Rojek, C. (2001). Celebrity. London: Routledge.

Rojek, C. (2012). Fame attack: The inflation of celebrity and its consequences. London: Bloomsbury.

Schlossberg, H. (1996). Sports marketing. Oxford: Blackwell Business.

Shuart, J. (2007). Heroes in sport: Assessing celebrity endorser effectiveness. International Journal of Sports Marketing \& Sponsorship, 1, 124-140.

Smith, L. (2006). Uses of heritage. London: Routledge.

Snyder, E. (1991). Sociology of nostalgia: Halls of fame and museums in America. Sociology of Sport Journal, 8, 228-38.

Standeven, J., \& De Knop, P. (1998). Sport tourism. Leeds: Human Kinetics.

Stewart, C. (2013). 2000: Cathy Freeman, olympic champion. The Weekend Australian Magazine. Retrieved from http://www.theaustralian.com.au/news/features/cathy-freeman-olympic-champion/ story-e6frg8h6-1226723751642

Stride, C., Wilson, J. P., \& Thomas, F. (2013). Honouring heroes by branding in bronze: Theorizing the UK's football statuary. Sport in Society, 16(6), 749-771.

Timothy, D. J., \& Boyd, S. W. (2006). Heritage tourism in the 21st Century: Valued traditions and new perspectives. Journal of Heritage Tourism, 1(1), 1-16.

Tunbridge, J., \& Ashworth, G. (1996). Dissonant heritage: The management of the past as a resource in conflict. Chichester: Wiley.

Turner, G. (2014). Understanding celebrity. London: Routledge.

Wann, D., Merrill, M., Russell, G., \& Pease, D. (2001). Sports fans: The psychology and social impacts of spectators. New York: Routledge.

Weed, M., \& Bull, C. (2009). Sports tourism: Participants, policy and providers. London: Butterworth-Heinemann.

Whannel, G. (1992). Fields in vision: Television, sport and cultural transformation. London: Routledge.

White, L. (2013). Cathy Freeman and Australia's indigenous heritage: A new beginning for an old nation at the Sydney 2000 Olympic Games. International Journal of Heritage Studies, 19(2), $153-170$. 